\title{
Pengaruh Kebiasaan Diri yang Buruk dan Kebiasaan di Era New Normal Terhadap Kinerja Driver Gojek di Salatiga
}

\author{
Novy Haumahu ${ }^{1}$, Rosaly Franksiska ${ }^{2 *}$ \\ 1,2Universitas Kristen Satya Wacana, Salatiga - Indonesia
}

\section{A R T I C LE I N F O}

Article history:

Received October, 282021

Received in revised form

November, 172021

Accepted November , 23

2021

Available online December, 252021

\section{Kata Kunci:}

Gojek, kebiasaan buruk,

kebiasaan new normal,

kinerja.

Keywords:

Bad habits, gojek, habit, new normal, performance.

\begin{abstract}
A B S T R A K
Gojek merupakan suatu aplikasi transportasi online yang dominan digunakan di Indonesia berdasarkan survey Yayasan Lembaga Konsumen Indonesia (YLKI). Dengan terjadinya pandemi Covid-19 lahir kebiasaan kebiasaan baru yang disebut dengan New Normal yang membuat pola hidup driver Gojek berubah. Kebiasaan lain yang diteliti adalah kebiasaan diri yang buruk, yang mana menurut American Psychological Association generasi milenial merupakan generasi yang sering mengalami stres karena kebiasaan kebiasaan buruk yang mereka lakukan. Tujuan penelitian ini adalah untuk menganalisis apakah kebiasaan diri yang buruk dan kebiasaan era new normal ini berpengaruh terhadap kinerja driver Gojek di Salatiga. Populasi dalam penelitian ini tidak diketahui karena jumlah driver Gojek di Salatiga yang berubah-ubah, maka dari itu jumlah sampel yang terpenuhi dalam penelitian ini berjumlah 160 . Penelitian ini menggunakan jenis penelitian kuantitatif kausalitas dengan pendekatan kuantitatif. Metode pengujian hipotesis dalam penelitian ini menggunakan uji analisis regresi linear berganda. Berdasarkan hasil pengujian kebiasaan diri yang buruk tidak memiliki pengaruh terhadap kinerja driver Gojek di Salatiga, dibuktikan dengan nilai signifikansi yang dimiliki sebesar 0,548 lebih besar dari 0,05 . Hasil pengujian juga menyimpulkan kebiasaan di era new normal berpengaruh positif terhadap kinerja driver Gojek di Salatiga, dibuktikan dengan nilai signifikansi yang dimiliki sebesar 0,015 lebih kecil dari 0,05.
\end{abstract}

\section{A B S T R A C T}

Gojek is an application commonly used in Indonesia, based on a survey by the Yayasan Lembaga Konsumen Indonesia (YLKI). Since the Covid-19 pandemic emerged, various adaptations to new habits called the New Normal have been implemented, causing a change in the lifestyle of Gojek drivers. Another habit studied was bad habit, which according to the American Psychological Association is common in millennials and causes them to experience stress. The purpose of this study was to analyse whether bad habits and the New Normal habit affect Gojek drivers' performance in Salatiga. The respondents in this study were 160 Gojek drivers. Respondents' answers regarding bad habits are high, especially on the habit of drivers who sit for too long, in their routine of riding motorcycles. Based on the answers, the habits of the new normal era were also high, especially in the understanding of drivers in using masks correctly. This research was conducted using a quantitative causality method. The hypothesis testing using multiple linear regression analysis shows that bad habits and new normal habits simultaneously affect drivers' performance. On other hand, the habits of the new normal habit positively affect drivers' performance, while bad habits have no effect on the performance of Gojek drivers in Salatiga even though it was high.

\footnotetext{
Corresponding author.

E-mail : rosaly.franksiska@uksw.edu (Rosaly Franksiska)
} 


\section{Pendahuluan}

Kemampuan seseorang dalam bekerja dapat dilihat pada tingkat kinerjanya. Kinerja adalah perilaku yang ditunjukkan karyawan di tempat kerja, baik dilihat dari kuantitas kerjanya maupun kualitas kerjanya (Murty \& Hudiwinarsih, 2012). Hasil kerja yang baik tidak mudah untuk diperoleh, karena ada banyak faktor yang mempengaruhi, seperti faktor personal yang berasal dari diri sendiri maupun faktor non personal seperti lingkungan dan lain lain. Salah satu contoh faktor personal adalah kebiasaan. Kebiasaan didefinisikan sebagai titik temu antar ilmu pengetahuan yang diketahui seseorang, kemampuan kerja yang dimiliki dan kemauannya dimana ilmu pengetahuan sebagai cara pandang teoritis, kemampuan kerja merupakan cara mewujudkannya dan kemauan sebagai motif untuk melakukan pekerjaan tersebut (Covey, 2004). Kebiasaan ini tentunya dilakukan secara berulang karena yang melakukan mampu dan memiliki keinginan untuk melakukannya.

Kebiasaan dapat berubah kapan saja dikarenakan berbagai hal dan umumnya suatu kebiasaan berubah dikarenakan suatu situasi yang berubah pula seperti merubah pola makan karena suatu penyakit. Dewasa ini seluruh negara di muka bumi mengalami pandemi yang berasal dari virus SARS yang menimbulkan penyakit menular Coronavirus Disease-2019 (COVID19) (Siagian, 2020). World Health Organization (2020) menyatakan bahwa virus ini diperkirakan bertransmisi melalui kontak langsung, droplet, fomite, udara, darah, ibu ke anak, hewan ke manusia; oleh karena itu seluruh negara di dunia termasuk Indonesia menerapkan New Normal atau kebiasaan baru yang mana kebiasaan baru tersebut seperti menggunakan masker untuk mencegah transmisi virus melalui udara, menjaga jarak dengan orang orang sekitar agar tidak terjadi kontak fisik, menjaga kebersihan dan meningkatkan imunitas tubuh maka hal ini tentu akan melahirkan kebiasaan-kebiasaan yang baru.

Berdasarkan survey Yayasan Lembaga Konsumen Indonesia (YLKI) 72,6 persen responden memilih Gojek sebagai aplikasi transportasi online yang digunakan, diikuti 66,9\% dari Grab; 51 persen menggunakan aplikasi Uber serta 4,4 persen menggunakan My BlueBird (Yayasan Lembaga Konsumen Indonesia, 2017). 430 karyawan Gojek mengalami pemutusan hubungan kerja (PHK) yang disebabkan oleh perubahan struktur perusahaan saat pandemi Covid-19 terjadi, namun untungnya mitra Goride yang berjumlah cukup banyak tidak terdampak karena perhatian Gojek akan tertuju pada tiga bisnis utama yaitu trasportasi (Goride), jasa pesan antar makanan dan minuman (Gofood) dan pembayaran secara elektronik (GoPay) selama pandemic (Pertiwi, 2020) .Konsumen Gojek dan Grab turun drastis saat pandemi Covid-19, Gojek yang konsumennya mencapai 4 juta per hari turun hingga 2,5 juta dan begitu pula dengan Grab yang turun hingga 2 juta pengguna per hari (Nofian, 2020).

Guna menjaga angka angka tersebut tidak turun lebih jauh berbagai program baru dilakukan oleh pihak Gojek seperti program Jaga Kesehatan, Kebersihan, dan Keamanan (J3K) pada Gojek yang berlaku untuk konsumen maupun driver (Gojek, 2020). Pastinya para driver Gojek harus beradaptasi demi keselamatan dan kesehatan dirinya sendiri. Adaptasi ini yang akan menimbulkan kebiasaan-kebiasaan baru seperti lebih memperhatikan imunitas, memperhatikan kebersihan, dan yang biasanya sering berkumpul dengan driver lainnya harus dibatasi.

Selain kebiasaan di era New Normal pada penelitian ini kebiasaan diri juga menjadi masalah yang akan diteliti pengaruhnya terhadap kinerja. American Psychological Association (APA) menemukan bahwa milenial merupakan generasi yang lebih sering mengalami stress dan juga tidak produktif dibandingkan dengan generasi generasi yang lain dikarenakan beberapa kebiasaan buruk seperti sistem tidur yang buruk, pola makan yang tidak baik, meminum kopi, durasi duduk yang tidak baik, penggunaan telepon yang berlebihan, waktu kerja yang tidak teratur, menonton TV secara berlebihan dan nongkrong dengan orang yang mudah cemas (Beaton, 2017). Kebiasaan kebiasaan buruk tersebut jika secara menerus dilakukan akan memperburuk kesehatan baik fisik maupun mental yang tentunya akan berpengaruh terhadap kinerja mereka.

Seperti yang sudah disebutkan sebelumnya kinerja dipengaruhi oleh banyak faktor. Berdasarkan penelitian terdahulu menggambarkan bahwa secara simultan kepuasan kerja, insentif dan motivasi berpengaruh positif dan signifikan terhadap kinerja driver GrabBike (Lailiyah \& Wahyuningsih, 2019). Penelitian Giri dan Dewi (2017); Djuharni dan Pangesti (2020) meneliti faktor-faktor yang mempengaruhi pendapatan driver dan apa yang memotivasi driver. Mangifera dan Isa (2017) meneliti pengaruh komitmen terhadap kinerja driver. Kebiasaan diri juga menjadi perhatian yang dapat mempengaruhi kinerja seperti penelitian pada siswa Sekolah Menengah Atas kota Abuja, Nigeria menunjukan bahwa prestasi akademik yang rendah dipengaruhi oleh kebiasaan belajar yang buruk (Ebele \& Olofu, 2017). Penelitian serupa mengenai prestasi akademik juga dilakukan di Universitas Kedokteran King Edward dan menemukan bahwa kualitas tidur mahasiswa yang berkaitan dengan kebiasaan tidak berpengaruh pada prestasi akademik (Tahir et al., 2014). Bissell (2013) pada penelitiannya menyatakan untuk mendapatkan kinerja yang terampil dibutuhkan kebiasaan yang baik dan dilakukan secara berulang; namun kebiasaan yang 
berulang juga akan menjadi suatu kebiasaan yang kuat dan akan sulit untuk keluar dari kebiasaan tersebut (Webb et al., 2009). Kebiasaan merupakan suatu hal yang berpotensi mempengaruhi kinerja namun masih sedikit penelitian yang dilakukan terutama kebiasaan diri. Masih sedikitnya penelitian yang secara khusus meneliti tentang kebiasaan baru yang lahir dari pandemi Covid-19 dan juga kebiasaan buruk yang dimiliki generasi Millenial terhadap kinerja mitra transportasi online, sehingga penelitian ini mencoba menguji variabel-variabel ini.

Maka dari itu persoalan penelitian ini yaitu apakah kebiasaan diri yang buruk dan kebiasaan era new normal berpengaruh terhadap kinerja driver Gojek di Salatiga? Tujuan penelitian ini yaitu untuk menganalisis apakah kebiasaan diri yang buruk dan kebiasaan era new normal ini berpengaruh terhadap kinerja driver Gojek di Salatiga.

Ada berbagai manfaat dalam penelitian ini antara lain diharapkan penelitian ini secara akademis akan memberi kontribusi ilmiah yang baru terkait hal kinerja di masa pandemi. Kajian tentang faktor faktor yang berpengaruh terhadap kinerja sudah cukup banyak namum masih sedikit yang melakukan riset mengenai kebiasaan seseorang terutama pada saat terjadinya pandemi. Secara praktis diharapkan penelitian ini dapat bermanfaat terhadap driver maupun pembuat kebijakan terhadap driver transportasi online dalam menghadapi era new normal ini.

\section{Tinjauan Pustaka Kinerja}

Kinerja adalah hasil kerja seseorang atau kelompok dalam organisasi yang dicapai sesuai dengan tanggung jawab dan wewenang masing-masing guna mencapai tujuan dari organisasi (Syarifah et al., 2020). Dalam setiap pekerjaan akan ada tanggung jawab yang perlu dipenuhi guna memenuhi tujuan organisasi yang sudah ditentukan dan tanggung jawab itu akan terpenuhi dengan hasil kerja yang baik. Menurut Kartika dan Sugiarto (2016), kinerja merupakan output dari indikator-indikator atau fungsi-fungsi suatu profesi atau pekerjaan pada jangka waktu tertentu. Istilah kinerja ini digunakan untuk mengukur kegiatan atau aktifitas seorang karyawan maupun perusahaan dalam kurun waktu tertentu dan pada akhirnya akan berguna untuk menjadi evaluasi. Kinerja dapat digunakan sebagai suatu ukuran perbandingan baik buruknya suatu organisasi melalui hasil yang dicapai sesuai dengan tujuan organisasi (Sofyan, 2013).

Menurut Mathis dan Jackson (2019) pada dasarnya kinerja merupakan apa yang dikerjakan dan tidak dikerjakan oleh karyawan. Banyaknya kontribusi yang diberikan karyawan terhadap organisasi seperti kuantitas serta kualitas hasil kerja, lama waktu pencapaian kerja, absensi dan tindakan yang koperatif ditentukan juga oleh kinerja karyawan (Kartika \& Sugiarto, 2016). Hasil kerja inilah yang disebut dengan kinerja dan akan terlihat pengaruhnya baik buruknya terhadap organisasi di mana seorang individu tersebut bekerja. Singkatnya, kinerja adalah suatu hasil dari pekerjaan suatu kelompok atau individu yang selaras dengan keputusan manajemen guna memenuhi tujuan tertentu secara efektif serta efisien (Effendi, 2013).

Kedisiplinan kerja, lingkungan pekerjaan dan tradisi kerja adalah tiga variabel yang bisa memajukan hasil kerja sumber daya manusia (Arianto, 2013). Tiga variabel tersebut sangat menentukan kinerja seseorang dalam bidang pekerjaan apapun tidak terkecuali driver transportasi online. Gojek yang merupakan perusahaan penyedia jasa transportasi online tidak memberikan target yang wajib dicapai terhadap driver namun driver yang bisa meraih target poin tertentu justru diberikan reward berupa tambahan bonus. Guna mendapat bonus tersebut tentunya driver harus memiliki kedisiplinan bekerja yang bagus serta lingkungan pekerjaan yang baik akan mendukung kinerja driver tersebut.

\section{Kebiasaan Diri}

Kebiasaan merupakan tanggapan atau reaksi yang cenderung terjadi secara otomatis dengan dipicu oleh aspek konteks kerja dalam hal ini adalah lingkungan dan tindakan terdahulu (Neal et al., 2006). Kebiasaan dapat terjadi jika sebelumnya hal tersebut sudah pernah dilakukan dan biasanya dilakukan secara berulang. Kebiasaan dapat berkonotasi positif maupun negatif karena ada kebiasaan yang baik untuk dilakukan dan ada juga kebiasaan buruk yang jika dilakukan terus menerus akan memperburuk keadaan sehingga harus dihentikan. Diperlukan klasifikasi yang lebih mendalam mengenai kebiasaan yang baik dan buruk karena suatu kebiasaan baik dapat berubah menjadi kebiasaan buruk contohnya pada media yang meliput alam yang awalnya dianggap baik namun ketika alam tersebut merasa terganggu maka hal itu menjadi kebiasaan yang buruk (LaRose et al., 2003). Riset yang dikerjakan oleh Ismawati et al, (2019) memperkuat hasil riset sebelumnya dengan menemukan bahwa kebiasaan mengunyah sirih yang secara adat dianggap baik untuk kesehatan gigi ternyata menimbulkan dampak buruk yaitu kurang memperhatikan kebersihan mulut dan membuang residu sirih dengan sembarangan.

Kebiasaan diri dalam penelitian ini membahas tentang kebiasaan diri yang buruk. Kebiasaan diri ini cenderung tidak sulit untuk diklasifikasi baik atau buruknya. Klasifikasi baik dan buruknya dapat dilihat 
langsung apakah dampak yang akan terjadi kepada individu tersebut. Kebiasaan diri yang buruk dapat membuat seseorang menjadi tidak produktif dan juga dapat mengganggu kesehatan mental seseorang. Seperti penelitian yang dilakukan American Psychology Association (APA) milenial merupakan generasi yang paling tinggi tingkat stressnya dan juga tidak produktif dikarenakan kebiasaan kebiasaan seperti sistem tidur yang buruk, pola makan yang tidak baik, meminum kopi, durasi duduk yang tidak baik, penggunaan telepon yang berlebihan, waktu kerja yang tidak teratur, menonton TV secara berlebihan dan nongkrong dengan orang yang mudah cemas (Beaton, 2017).

Kebiasaan kebiasaan buruk tersebut tidak langsung berdampak terhadap produktifitas seseorang namun dampaknya akan menyerang kesehatan fisik atau mental terlebih dahulu. Pola tidur yang buruk jika tidak ditangani akan berpotensi meningkatkan resiko munculnya beberapa penyakit seperti hipertensi dan penyakit jantung (Willy, 2019). Pola makan yang tidak baik pada tahun 2017 menyebabkan kematian terhadap sekitar 11 juta jiwa di seluruh dunia dan penyakit jantung, kanker dan diabetes tipe 2 merupakan penyebab kematian 10 juta jiwa dari total kematian tersebut (Anggraini, 2019). Kafein dalam kandungan kopi mampu meningkatkan kewaspadaan dengan memblokir adenosine yang membuat tubuh lelah namun jika dikonsumsi secara berlebihan setiap hari dapat menyebabkan kecemasan dan kegugupan (Tashandra, 2020). Menonton TV secara berlebihan tidak baik untuk otak, hal ini didukung oleh riset dari Northern California Institute for Research and Education yang menunjukan sejumlah 3.200 orang dengan usia rata rata 25 tahun memiliki kerja kognotif otak yang tidak baik saat lebih dari tiga jam per hari menonton TV (Anwar, 2016).

\section{Persepsi Kebiasaan di Era New Normal}

Pemerintah di berbagai negara serta World Health Organization (WHO) mengeluarkan maklumat tatanan baru agar hidup berdampingan dengan Covid-19, dengan pandangan "New Normal" karena ketidakpastian akhir dari pandemi (Mas'udi \& Winanti, 2020). Pandemi tersebut berasal dari virus yang dikenal dengan nama Severe Acute Respiratory Syndrome Coronavirus 2 (SARS-COV2), yang merupakan lahirnya penyakit Coronavirus Disease-2019 (COVID19) dan penyakit ini pertama dilaporkan terjadi pada 8 Desember 2019 di kota Wuhan, Provinsi Hubei, China (Siagian, 2020). Menurut World Health Organization (2020) virus ini diperkirakan dapat bertransmisi melalui kontak langsung, droplet, fomite, udara, darah, ibu ke anak, hewan ke manusia.

Bagian dari new normal yang diterapkan di setiap negara umumnya adalah menggunakan masker untuk mencegah transmisi virus melalui udara, menjaga jarak dengan orang orang sekitar agar tidak terjadi kontak fisik, menjaga kebersihan dan meningkatkan imunitas tubuh. Selain menghimbau seluruh masyarakat untuk menjaga kesehatan dan kebersihan World Health Organization (2020a) juga menyarankan agar tempat-tempat tertentu seperti tempat yang terbatas dan tertutup, tempat ramai, tempat yang sempit untuk dihindari. Pemerintah Indonesia ikut memberikan panduan kepada masyarakat mengenai kehidupan normal baru yang harus dilaksanakan dalam 7 norma yaitu mencuci tangan, menghindari menyentuh area wajah, menjalankan etika batuk dan bersin, gunakan masker sewaktu keluar rumah atau berinteraksi dengan orang lain, menjaga jarak sosial, isolasi mandiri jika merasa tidak dalam kondisi sehat, menjaga kondisi kesehatan dengan memastikan kesehatan fisik (Muhyiddin \& Kementerian Perencanaan Pembangunan Nasional/Bappenas Republik Indonesia, 2020). Hal ini tentu akan melahirkan kebiasaan-kebiasaan yang baru. Setiap orang mulai menjaga jarak agar tidak terjadi kontak fisik langsung, mulai memperhatikan kebersihan dan lebih peka terhadap kesehatan.

Hampir semua pekerjaan merasakan dampak dari pandemi Covid-19 ini dan dipaksakan untuk beradaptasi. Gojek dan Grab yang merupakan dua perusahaan penyedia jasa transportasi online terbesar di Indonesia terpaksa harus beradaptasi dengan peraturan peraturan kehidupan normal baru. Adaptasi yang dilakukan seperti pengecekan suhu tubuh para driver secara rutin dan penyemprotan disinfektan terhadap kendaraan (Gojek, 2020). Demi keamanan penumpang juga disediakan sekat antara driver dengan penumpang dan juga pembatasan jumlah penumpang dalam satu mobil yaitu hanya sebanyak dua penumpang (Clinten, 2020). Adaptasi yang dilakukan ini akan melahirkan kebiasaan kebiasaan baru pada era New Normal yang tidak pasti kapan akan berakhir.

\section{Pengembangan Hipotesis}

Pada penelitian Nonis dan Hudson (2010) mengenai pengaruh waktu belajar terhadap kinerja akademik dimoderasi oleh kebiasaan belajar berpengaruh positif, namun waktu belajar akan lebih berpengaruh kepada kinerja pelajar ketika pelajar lebih berkonsentrasi. Penelitian mengenai kinerja akademik juga dilakukan oleh Titus et al., (2016) namun dengan variabel mempengaruhi yang berbeda yaitu kebiasaan sosial diadaptasi dari fenomena pernikahan muda yang terjadi dan hasil penelitiaannya kebiasaan sosial yang terjadi mempengaruhi kinerja akademik para pelajar yang menikah muda. Penelitian mengenai kinerja akademik ini juga dilakukan pada mahasiswa seperti pada penelitian Reuter et al., (2020) 
menemukan bahwa kebiasaan makan yang sehat mempengaruhi secara signifikan terhadap kinerja akademik. Objek penelitian lain mengenai kinerja yang sering ditemukan yaitu pada atlit seperti pada penelitiaan Silva dan Paiva, (2016); Takeda et al., (2020) menyimpulkan bahwa kebiasaan waktu tidur yang tidak baik berpengaruh terhadap performa atau kinerja atlit.

Berdasarkan penelitian-penelitian yang tecantum di atas bisa dilihat bahwa tidak sedikit jenis kebiasaan yang dapat berpengaruh terhadap kinerja namun kebiasaan diri yang buruk belum banyak diteliti. Kebiasaan diri yang buruk tersebut beracuan dari penelitian dari American Psychology Association yang menyimpulkan beberapa kebiasaan buruk seperti sistem tidur yang buruk, pola makan yang tidak benar, meminum kopi, durasi duduk yang tidak baik, penggunaan telepon yang berlebihan, waktu kerja yang tidak teratur, menonton TV secara berlebihan dan nongkrong dengan orang yang mudah cemas (Beaton, 2017). Berlandaskan pernyataan di atas, sehingga hipotesis yang diajukan pada penelitian ini adalah:

\section{$\mathrm{H}_{1}$ : Ada pengaruh negatif kebiasaan diri terhadap kinerja.}

Pada masa pandemic covid19 ini, driver ojek online terdampak cukup besar dikarenakan berkurangnya konsumen ojek online, hal ini menyebabkan banyak driver ojek online mengalami kesulitan ekonomi dan mempengaruhi kesejahteraan hidup dan menimbulkan stress pada diri mereka (Hapsari et al., 2021). Selain kebiasaan diri yang buruk, kebiasaan baru di era New Normal juga belum banyak diteliti karena fenomenanya yang belum lama terjadi. Objek penelitian yang diteliti juga jarang ditemui mengenai pekerja di lapangan seperi driver transportasi online. Berdasarkan pernyataan di atas, maka hipotesis yang diajukan dalam penelitian ini adalah:

\section{$\mathrm{H}_{2}$ : Ada pengaruh positif kebiasaan di era New Normal terhadap kinerja.}

Penelitian ini bertujuan untuk menganalisis apakah kebiasaan diri yang buruk dan kebiasaan era new normal ini berpengaruh terhadap kinerja driver Gojek di Salatiga. Guna mempermudah analisis dalam penelitian, maka dibuat model penelitian seperti gambar 1.

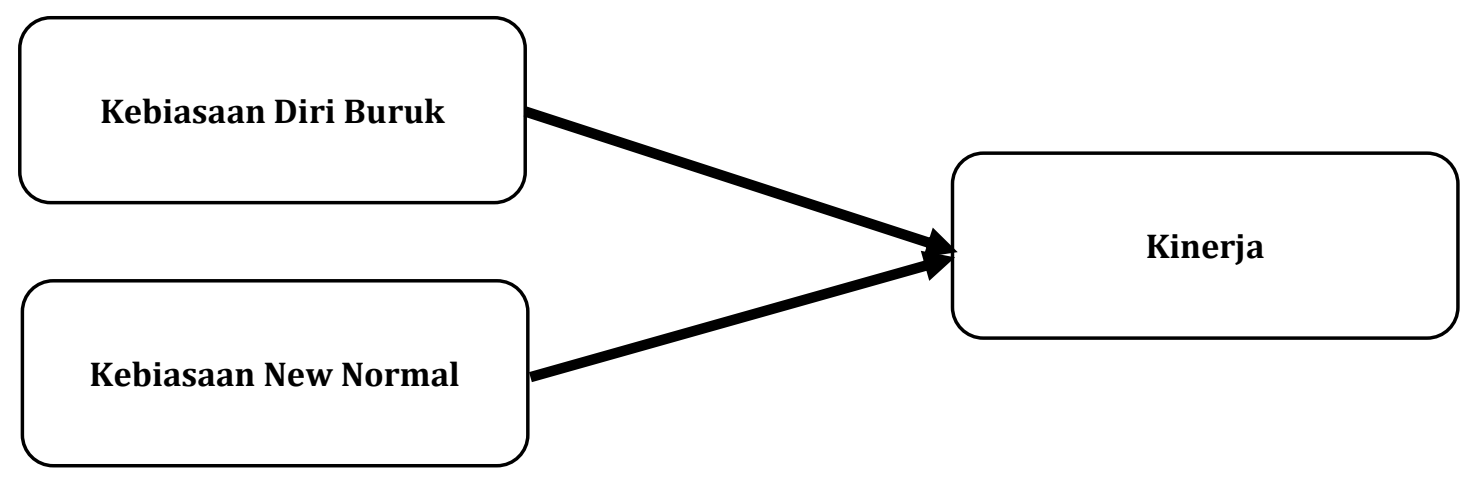

Gambar 1. Kerangka berpikir

\section{Metode}

Jenis penelitian yang digunakan pada penelitian ini adalah penelitian kuantitatif kausal. Penelitian ini bertujuan untuk menganalisis pengaruh antar suatu variabel dengan variabel lainnya secara obyektif. Pada penelitian ini variabel dependen (Y) adalah kinerja driver sedangkan variabel independen (X) adalah kebiasaan diri dan kebiasaan di era new normal. Populasi dalam penelitian ini tidak diketahui karena jumlah driver Gojek di Salatiga berubah-ubah seiring waktu dan jumlah yang aktif juga tidak diketahui secara pasti. Pengambilan sampel pada penelitian ini yaitu dengan menggunakan teknik non-probability sampling dengan menggunakan convenience sampling. Hair et al., (2014) menyatakan bahwa minimum sampel sebanyak 100 untuk penelitian dengan model regresi linear berganda sudah memenuhi syarat sehingga sampel yang dapat terpenuhi pada penelitian ini berjumlah 160. Dalam menentukan sampel menggunakan teknik sampling incidental sampling. Metode pengumpulan data dalam penelitian ini menggunakan kuesioner. Jawaban dari pernyataan atau pertanyaan nantinya akan diberikan skor yang mengacu pada skala likert. 
Tabel 1. Operasionalisasi Variabel

\begin{tabular}{|c|c|c|}
\hline Variabel dan Definisi & Dimensi & Indikator \\
\hline \multirow[t]{6}{*}{$\begin{array}{l}\text { Kinerja adalah hasil kerja karyawan } \\
\text { dari segi kualitas dan kuantitas atau } \\
\text { perilaku langsung yang ditunjukan } \\
\text { sesuai dengan tanggung jawab yang } \\
\text { dimiliki (Murty \& Hudiwinarsih, 2012) }\end{array}$} & Kualitas kerja & $\begin{array}{ll}\text { - } & \text { Kemampuan mengerjakan } \\
\text { pekerjaan } \\
\text { - } \quad \text { Ketrampilan dalam mengerjakan } \\
\text { pekerjaan } \\
\text { - } \quad \begin{array}{l}\text { Kesesuaian hasil kerja dengan } \\
\text { perintah }\end{array} \\
\end{array}$ \\
\hline & Kuantitas Kerja & $\begin{array}{l}\text { - } \quad \text { Kesesuaian waktu dalam bekerja } \\
\text { - } \quad \text { Pencapaian target pekerjaan }\end{array}$ \\
\hline & Inisiatif & $\begin{array}{l}\text { Kemandirian untuk } \\
\text { menyelesaikan pekerjaan }\end{array}$ \\
\hline & Kerjasama & $\begin{array}{ll}\text { - } & \text { Kerjasama antar rekan kerja } \\
\text { - } & \text { Kekompakan ketika bekerja sama } \\
\end{array}$ \\
\hline & Tanggung Jawab & $\begin{array}{l}\text { - } \\
\text { mensa tanggung jawab ketika } \\
\text { - } \quad \text { Rasa tanggung jawab terhadap } \\
\text { hasil kerja }\end{array}$ \\
\hline & Sumbe & (Mangkunegara, 2012) \\
\hline \multirow{8}{*}{$\begin{array}{l}\text { Kebiasaan didefinisikan sebagai } \\
\text { persimpangan antara pengetahuan, } \\
\text { keterampilan dan keinginan dimana } \\
\text { pengetahuan sebagai paradigma } \\
\text { teoritis, keterampilan adalah } \\
\text { bagaimana melakukannya dan } \\
\text { keinginan adalah motivasi untuk } \\
\text { melakukannya (Covey, 2004). } \\
\text { Klasifikasi baik dan buruknya kebiasaan } \\
\text { dapat dilihat langsung apakah dampak } \\
\text { yang akan terjadi kepada individu } \\
\text { tersebut. Kebiasaan diri yang buruk } \\
\text { dapat membuat seseorang menjadi } \\
\text { tidak produktif dan juga dapat } \\
\text { mengganggu kesehatan mental } \\
\text { seseorang. }\end{array}$} & $\begin{array}{l}\text { Terlalu sering } \\
\text { menonton TV }\end{array}$ & $\begin{array}{ll}\text { - } & \text { Mengikuti perkembangan terkini } \\
\text { - } & \text { Menyaksikan hiburan } \\
\text { - } & \text { Mencari informasi dan } \\
& \text { pengetahuan } \\
\end{array}$ \\
\hline & Lupa untuk istirahat & $\begin{array}{l}\text { - } \quad \text { Kerja hingga larut malam } \\
\text { - } \quad \text { Intensitas pekerjaan yang tinggi } \\
\text { - } \quad \text { Cakupan pekerjaan yang luas } \\
\text { (Bahri et al., 2012) }\end{array}$ \\
\hline & $\begin{array}{l}\text { Kebiasaan tidur yang } \\
\text { buruk }\end{array}$ & $\begin{array}{l}\text { - } \quad \text { Aktifitas fisik } \\
\text { - } \quad \text { Stress psikologis } \\
\text { - } \quad \text { Gaya hidup } \\
\text { (Safitrie \& Ardani, 2013) }\end{array}$ \\
\hline & $\begin{array}{l}\text { Pola makan tidak } \\
\text { teratur }\end{array}$ & $\begin{array}{l}\text { - } \quad \text { Melewatkan sarapan } \\
\text { - } \quad \text { Makan sebelum tidur } \\
\text { - } \quad \text { Kurang asupan buah dan sayur } \\
\text { (Niswah, 2016) }\end{array}$ \\
\hline & $\begin{array}{l}\text { Konsumsi kopi } \\
\text { berlebih }\end{array}$ & $\begin{array}{l}\text { - } \quad \text { Menghilngkan rasa kantuk } \\
\text { - } \quad \text { Meningkatkan kesadaran } \\
\text { - } \quad \text { Meningkatkan fokus } \\
\text { (Solikatun et al., 2015) }\end{array}$ \\
\hline & Terlalu lama duduk & $\begin{array}{l}\text { - } \quad \text { Menyelesaikan pekerjaan } \\
\text { - } \quad \text { Tidak menyadari berapa lama } \\
\text { waktu untuk duduk } \\
\text { - } \quad \text { Bekerja di depan komputer } \\
\text { (Madona et al., 2018) }\end{array}$ \\
\hline & $\begin{array}{l}\text { Sering bermain } \\
\text { ponsel }\end{array}$ & $\begin{array}{l}\text { - } \quad \text { Penggunaan media social } \\
\text { - } \quad \text { Untuk menelfon } \\
\text { - } \quad \text { Bermain game } \\
\text { (Nursalam \& Jamaluddin, 2016) }\end{array}$ \\
\hline & $\begin{array}{l}\text { Bergaul dengan orang } \\
\text { orang yang mudah } \\
\text { cemas }\end{array}$ & $\begin{array}{l}\text { - } \quad \text { Membutuhkan teman untuk } \\
\text { berbagi cerita } \\
\text { - Terbiasa bergaul dengan teman } \\
\text { teman yang merasa stress } \\
\text { (Beaton, 2017) }\end{array}$ \\
\hline $\begin{array}{l}\text { Kebiasaan di era new normal adalah } \\
\text { scenario untuk mempercepat }\end{array}$ & Menggunakan masker & $\begin{array}{l}\text { - Memahami cara memakai dan } \\
\text { melepas masker } \\
\text { - Skala pergantian masker }\end{array}$ \\
\hline
\end{tabular}




\begin{tabular}{|c|c|c|}
\hline Variabel dan Definisi & Dimensi & $\begin{array}{l}\text { Indikator } \\
\end{array}$ \\
\hline \multirow{5}{*}{$\begin{array}{l}\text { penanganan Covid-19 pada aspek } \\
\text { kesehatan dan social-economy }\end{array}$} & & - Jenis masker yang digunakan \\
\hline & Rutin mencuci tangan & $\begin{array}{l}\text { Frekuensi membersihkan tangan } \\
\text { per hari }\end{array}$ \\
\hline & $\begin{array}{l}\text { Menjaga jarak } \\
\text { minimal } 1 \text { meter }\end{array}$ & $\begin{array}{l}\text { - Terbiasa berkumpul dengan rekan } \\
\text { kerja lainnya } \\
\text { Berbincang dengan jarak dekat } \\
\text { antara satu dan lainnya }\end{array}$ \\
\hline & $\begin{array}{l}\text { Menghindari tempat } \\
\text { ramai }\end{array}$ & $\begin{array}{l}\text { - Saat kerja di lapangan cenderung } \\
\text { memperhatikan sekitar } \\
\text { - Peka dengan situasi ramai }\end{array}$ \\
\hline & $\begin{array}{l}\text { Menjaga imunitas } \\
\text { tubuh }\end{array}$ & $\begin{array}{l}\text { Mengkonsumsi makanan dan } \\
\text { minuman bergizi } \\
\text { - } \text { Istirahat yang cukup } \\
\end{array}$ \\
\hline
\end{tabular}

Analisis data yang digunakan pada penelitian ini mencakup pretest kuesioner (uji validitas dan uji reliabilitas). Uji selanjutnya yaitu uji asumsi klasik sebagai syarat yang harus dipenuhi sebelum uji hipotesis. Uji asumsi klasik yang digunakan yaitu uji normalitas, uji multikolinieritas, uji heteroskedastisitas dan uji linearitas. Uji hipotesis menggunakan analisis regresi linier berganda. Teknik pengujian hipotesis adalah suatu teknik untuk menguji kebenaran adanya keterkaitan sebab-akibat dengan menggunakan simpulan sementara karena kebenarannya masih perlu dibuktikan. Pengujian hipotesis bisa dilakukan dengan cara simultan dan parsial yang memanfaatkan uji t (parsial) dan uji $f$ (simultan) menggunakan teknik probabilitas dengan membandingkan nilan probabilitas dan nilai signifikan 0,05 . Saat nilai probabilitas sig $<0,05$ maka dikatakan signifikan dan hipotesis diterima jika benar serta ditolak jika salah.

\section{Hasil dan pembahasan}

Pretest kuesioner berupa uji validitas yang bertujuan untuk mengetahui data yang dikumpulkan valid atau tidak, data akan dikatakan valid apabila pada kolom Corrected Item-Total Correlation memiliki rhitung $>0,159$. Kemudian untuk dapat lolos tes reliabilitas maka nilai dari cronbach alpha harus $>0,6$. Jika angka-angka tersebut terpenuhi maka dapat ditari kesimpulan bahwa hasil olahan data dari penelitian ini lolos Uji Validitas dan Reliabilitas. Tiga variabel yang diuji ketiganya memenuhi uji reliabilitas. Pada Uji Validitas, dari 44 item pernyataan, terdapat beberapa indikator yang hasilnya tidak valid namun tidak mempengaruhi pengukuran dimensi dari masing masing variabel. Dalam pengujian berikutnya indikator yang tidak valid akan tidak diperhitungkan.

\section{Uji Asumsi Klasik}

Guna mengetahui frekuensi penyebaran data yang normal ataupun tidak normal dapat digunakan uji asumsi klasik yang pertama adalah Uji Normalitas. Data terdistribusi normal bila nilai signifikan tiap variable $>0,05$ yang mana artinya pada penelitian ini data terdistribusi normal dengan nilai signifikansi variabel kebiasaan buruk 0,065 >0,05; variabel kebiasaan new normal 0,067 >0,05; variabel kinerja 0,060 $>0,05$.

Uji asumsi klasik yang kedua adalah Uji Heterokedastisitas. Hasil pengolahan data menunjukkan bahwa nilai signifikansi variabel kebiasaan buruk (X1) sebesar 0,522 $>0.05$; variabel kebiasaan new normal (X2) sebesar 0,733 > 0,05 maka dapat disimpulkan bahwa model regresi tersebut tidak mengandung heterokedastisitas.

Guna mengetahui adanya korelasi antar variable independen dalam regresi ini maka digunakan uji asumsi klasik berikutnya yaitu Uji Multikolinearitas. Hasil pengolahan data pada penelitian ini menunjukan variabel kebiasaan buruk memiliki nilai tolerance 0,992 $>0,10$ dan nilai VIF 1,008 $<10$, pada variabel kebiasaan new normal nilai tolerance $0,992>0,1$ dan nilai VIF $1,008<10$ maka disimpulkan tidak terjadi multikolinearitas pada kedua variabel independen tersebut.

Uji Linearitas adalah instrumen terakhir pada uji asumsi klasik yang berguna untuk melihat ada atau tidaknya hubungan yang linear dalam sebuah variabel. Berdasarkan Deviation from linearity variabel kebiasaan buruk (X1) dengan nilai 0,152 >0,05 maka disimpulkan terdapat hubungan linear antara Kebiasaan Buruk (X1) dengan Kinerja (Y). Berdasarkan Deviation from linearity variabel kebiasaan new normal dengan nilai 0,118 $>0,05$ maka disimpulkan terdapat hubungan linear antara Kebiasaan New Normal (X2) dengan Kinerja (Y). 


\section{Karakteristik Responden}

Pada bagian ini ini akan dijelaskan karakteristik responden yang berjumlah 160 orang yang merupakan driver gojek di Salatiga. Karakteristik tersebut terdiri dari jenis kelamin, rentang umur, pendidikan terakhir, rentang lama bekerja, lokasi bekerja, dan status perkawinan yang akan disajikan dalam table 2 .

Tabel 2. Karakteristik Responden

\begin{tabular}{|c|c|c|c|}
\hline \multicolumn{2}{|c|}{ Karakteristik Responden } & \multirow{2}{*}{$\begin{array}{c}\text { Frekuensi } \\
158\end{array}$} & \multirow{2}{*}{$\begin{array}{c}\text { Presentasi } \\
98,75 \%\end{array}$} \\
\hline \multirow{3}{*}{ Jenis Kelamin } & Pria & & \\
\hline & Wanita & 2 & $1,25 \%$ \\
\hline & Total & 160 & $100 \%$ \\
\hline \multirow{4}{*}{ Umur } & $<20$ Tahun & 7 & $4,38 \%$ \\
\hline & 20-40 Tahun & 94 & $58,75 \%$ \\
\hline & >40 Tahun & 59 & $36,87 \%$ \\
\hline & Total & 160 & $100 \%$ \\
\hline \multirow{5}{*}{$\begin{array}{l}\text { Pendidikan } \\
\text { Terakhir }\end{array}$} & SMA/SMK & 135 & $84,38 \%$ \\
\hline & D3 & 11 & $6,87 \%$ \\
\hline & S1 & 14 & $8,75 \%$ \\
\hline & Lain-lain & 0 & $0 \%$ \\
\hline & Total & 160 & $100 \%$ \\
\hline \multirow{5}{*}{ Lama Bekerja } & $<1$ Tahun & 10 & $6,25 \%$ \\
\hline & 1-3 Tahun & 80 & $50 \%$ \\
\hline & 3-6 Tahun & 70 & $43,75 \%$ \\
\hline & $>6$ Tahun & 0 & $0 \%$ \\
\hline & Total & 160 & $100 \%$ \\
\hline \multirow{3}{*}{$\begin{array}{c}\text { Lokasi Wilayah } \\
\text { Kerja }\end{array}$} & Salatiga & 160 & $100 \%$ \\
\hline & Lain Lain & 0 & $0 \%$ \\
\hline & Total & 160 & $100 \%$ \\
\hline \multirow{3}{*}{ Status Perkawinan } & Single & 31 & $19,38 \%$ \\
\hline & Menikah & 129 & $80,62 \%$ \\
\hline & Total & 160 & $100 \%$ \\
\hline
\end{tabular}

Sumber: Data Olahan, 2021

Tabel 2 menunjukan bahwa responden didominasi oleh driver berjenis kelamin pria sebanyak 98,75\% dari 160 responden dan hanya 2 responden berjenis kelamin wanita. 58,75\% dari 160 responden berusia 20-40 tahun diikuti oleh para driver berusia 40 tahun keatas sebanyak 36,87\% dan usia remaja hanya 4,38\%. Dalam bidang pendidikan banyak driver yang menjadi responden menempuh pendidikan sampai jenjang Sekolah Menengah Atas (SMA) dan Sekolah Menengah Kejuruan (SMK). Sebanyak 84,38\% responden menempuh pendidikan hingga SMA/SMK, ada juga lulusan S1 dan D3 yang menjadi responden dalam penelitian ini dengan jumlah masing masing 8,75\% dan 6,87\% dari total 160 responden.

Setengah dari jumlah responden telah menekuni pekerjaan mereka selama 1-3 tahun belakangan, dan sebanyak 43,75\% responden bekerja sebagai driver selama 3-6 tahun. Seluruh responden dalam penelitian ini bekerja di wilayah Salatiga. Sebanyak 80,62\% dari 160 responden telah menikah dan berkeluarga sedangkan 19,38\% masih berstatus belum menikah.

\section{Kebiasaan Diri, Kebiasaan New Normal dan Kinerja}

Guna mengetahui tinggi rendahnya variabel rata-rata jawaban responden dalam kuesioner dengan dapat dicari degan mengurangi nilai tertinggi dengan nilai terendah pilihan jawaban, relatif terhadap banyaknya kategori yang diinginkan (dalam hal ini 5), maka nilai jarak intervalnya adalah 0,8.

Tabel 3. Tingkat Kategori Variabel

\begin{tabular}{cc}
\hline Range & Keterangan \\
\hline $4-4,79$ & Sangat Tinggi \\
$3,2-3,99$ & Tinggi \\
$2,4-3,19$ & Sedang \\
$1,6-2,39$ & Rendah \\
$0,8-1,59$ & Sangat Rendah \\
\hline
\end{tabular}


Guna mengetahui kategori dari setiap variabel berdasarkan mean atau rata-ratanya, berikut tabel penjelasan dari setiap variabel:

Tabel 4. Kebiasaan Diri

\begin{tabular}{clcc}
\hline No & \multicolumn{1}{c}{ Pernyataan } & Mean & Kategori \\
\hline 1 & Mengikuti perkembangan terkini dari menonton TV & 3,07 & Sedang \\
2 & Menyaksikan hiburan dari menonton TV & 3,14 & Sedang \\
3 & Mencari informasi dan pengetahuan dari TV & 3,33 & Tinggi \\
4 & Lupa untuk istirahat karena kerja hingga larut malam & 3,19 & Sedang \\
5 & Lupa untuk istirahat karena intensitas pekerjaan yang tinggi & 3,09 & Sedang \\
6 & Lupa untuk istirahat karena cakupan pekerjaan yang luas & 3,77 & Tinggi \\
7 & Kebiasaan tidur yang buruk karena aktifitas fisik & 3,29 & Tinggi \\
8 & Kebiasaan tidur yang buruk karena stress psikologis & 3,31 & Tinggi \\
9 & Kebiasaan tidur yang buruk karena gaya hidup & 3,04 & Sedang \\
10 & Pola makan tidak teratur dengan melewatkan sarapan & 2,85 & Sedang \\
11 & Pola makan tidak teratur dengan makan sebelum tidur & 3,29 & Tinggi \\
12 & Pola makan tidak teratur dengan kurang asupan buah dan & 2,88 & Sedang \\
& sayur & & \\
13 & Menghilngkan rasa kantuk dengan mengkonsumsi kopi & 3,46 & Tinggi \\
& berlebih & & \\
14 & Meningkatkan kesadaran dengan mengkonsumsi kopi & 3,29 & Tinggi \\
& berlebih & & \\
15 & Meningkatkan fokus dengan mengkonsumsi kopi berlebih & 3,33 & Tinggi \\
16 & Menyelesaikan pekerjaan dengan terlalu lama duduk & 3,97 & Tinggi \\
17 & Tidak menyadari berapa lama waktu untuk duduk & 3,83 & Tinggi \\
18 & Bekerja di depan komputer & 3,63 & Tinggi \\
19 & Sering bermain ponsel karena penggunaan media sosial & 3,96 & Tinggi \\
20 & Sering bermain ponsel untuk menelfon & 3,94 & Tinggi \\
21 & Sering menggunakan ponsel untuk bermain game & 3,15 & Sedang \\
22 & Membutuhkan teman untuk berbagi cerita & 3,69 & Tinggi \\
23 & Terbiasa bergaul dengan teman teman yang merasa stress & 3,41 & Tinggi \\
\hline & $\quad$ Total Kebiasaan Diri & 3,39 & Tinggi \\
& & & \\
\hline
\end{tabular}

Tabel 4 menunjukan bahwa nilai rata-rata variabel Kebiasaan Diri sebesar 3,39 yang termasuk dalam kategori tinggi. Nilai rata-rata terendah terdapat pada pernyataan "Pola makan tidak teratur dengan melewatkan sarapan" dengan nilai 2,85. Nilai rata-rata tertinggi terdapat pada pernyataan "Menyelesaikan pekerjaan dengan terlalu lama duduk" dengan nilai 3,97.

Tabel 5. Kebiasaan New Normal

\begin{tabular}{clcc}
\hline No & \multicolumn{1}{c}{ Pernyataan } & Mean & Kategori \\
\hline 1 & Memahami cara memakai masker yang benar & 4,48 & Sangat Tinggi \\
2 & Memahami cara melepas masker yang benar & 4,41 & Sangat Tinggi \\
3 & Melakukan skala pergantian masker yang benar & 3,58 & Tinggi \\
4 & Jenis masker yang digunakan sesuai dengan anjuran & 3,97 & Tinggi \\
5 & Frekuensi membersihkan tangan per hari & 4,09 & Sangat Tinggi \\
6 & Terbiasa berkumpul dengan rekan kerja lainnya & 1,84 & Rendah \\
7 & Berbincang dengan jarak dekat antara satu dan lainnya & 3,91 & Tinggi \\
8 & Saat kerja di lapangan cenderung memperhatikan & 3,40 & Tinggi \\
& sekitar & 3,79 & Tinggi \\
9 & Peka dengan situasi ramai guna menghindari & & \multirow{2}{*}{ Tinggi } \\
& kerumunan & & \\
10 & Mengkonsumsi makanan dan minuman bergizi guna & 3,87 & Tinggi \\
& menjaga imun tubuh. & 3,84 & Tinggi \\
\hline \multicolumn{2}{c}{ Tstirahat yang cukup guna menjaga imun tubuh } & $\mathbf{3 , 7 4}$ & \\
\hline
\end{tabular}


Nilai rata-rata pada variabel Kebiasaan New Normal adalah 3,74 yang mana dalam kategori tinggi. Nilai rata-rata tertinggi pada variabel Kebiasaan New Normal adalah pada pernyataan "Memahami cara memakai masker yang benar" dengan nilai 4,48. Nilai rata-rata terendah pada variabel ini terletak pada pernyataan "Terbiasa berkumpul dengan rekan kerja lainnya” dengan nilai 1,84.

Tabel 6. Kinerja

\begin{tabular}{clcc}
\hline No & \multicolumn{1}{c}{ Pernyataan } & Mean & Kategori \\
\hline $\mathbf{1}$ & Kemampuan mengerjakan pekerjaan & 4,2 & Sangat Tinggi \\
$\mathbf{2}$ & Ketrampilan dalam mengerjakan pekerjaan & 4,31 & Sangat Tinggi \\
$\mathbf{3}$ & Kesesuaian hasil kerja dengan perintah & 3,95 & Tinggi \\
$\mathbf{4}$ & Kesesuaian waktu dalam bekerja & 4,42 & Sangat Tinggi \\
$\mathbf{5}$ & Pencapaian target pekerjaan & 3,25 & Tinggi \\
$\mathbf{6}$ & Kemandirian untuk menyelesaikan pekerjaan & 3,78 & Tinggi \\
$\mathbf{7}$ & Menjalani Kerjasama dengan sesama rekan kerja & 3,95 & Tinggi \\
$\mathbf{8}$ & Kekompakan ketika bekerja sama dengan sesame & 3,68 & Tinggi \\
& rekan kerja & & \\
$\mathbf{9}$ & Rasa tanggung jawab ketika mengambil keputusan & 4,65 & Sangat Tinggi \\
$\mathbf{1 0}$ & Rasa tanggung jawab terhadap hasil kerja & 4,61 & Sangat Tinggi \\
\hline & $\quad$ Total Kinerja & $\mathbf{4 , 0 8}$ & Sangat Tinggi \\
\hline
\end{tabular}

Pada tabel 6 ditunjukan bahwa rata-rata tertinggi pada variabel Kinerja adalah pada pernyataan "Rasa tanggung jawab ketika mengambil keputusan" dengan nilai 4,65. Rata-rata terendah namun masih dalam kategori tinggi dalam variabel ini dengan nilai 3,25 terletak pada pernyataan " Pencapaian target pekerjaan".

\section{Uji Hipotesis}

Metode pengujian hipotesis ini menggunakan uji analisis regresi linear berganda, pengujian ini digunakan untuk mengetahui ada atau tidaknya pengaruh yang diberikan variabel bebas terhadap variabel terikat. Dasar yang digunakan pada pengujian ini adalah jika nilai sig < 0,05 maka dapat disimpulkan bahwa variabel bebas berpengaruh terhadap variabel terikat. Hasil uji dapat dilihat di lampiran 3.

\begin{tabular}{lcccc}
\multicolumn{5}{c}{ Model Summary } \\
\hline Model & R & R Square & $\begin{array}{l}\text { Adjusted } \\
\text { R Square }\end{array}$ & $\begin{array}{c}\text { Std. Error of the } \\
\text { Estimate }\end{array}$ \\
\hline 1 & $.195^{\mathrm{a}}$ & .038 & .026 & 4.403 \\
\hline a. Predictors: (Constant), Kebiasaan New Normal, Kebiasaan Buruk
\end{tabular}

\begin{tabular}{llrrrrr}
\multicolumn{7}{c}{ ANOVA $^{\mathbf{b}}$} \\
Model & Sum of Squares & df & Mean Square & F & Sig. \\
\hline \multirow{2}{*}{1} & 120.598 & 2 & 60.299 & 3.110 & $.047^{\mathrm{a}}$ \\
\cline { 2 - 7 } & Regression & 3044.177 & 157 & 19.390 & & \\
\cline { 2 - 7 } & Residual & 3164.775 & 159 & & & \\
\cline { 2 - 7 } & Total & &
\end{tabular}

a. Predictors: (Constant), Kebiasaan New Normal, Kebiasaan Buruk

b. Dependent Variable: kinerja

\begin{tabular}{|c|c|c|c|c|c|c|}
\hline \multicolumn{7}{|c|}{ Coefficients $^{a}$} \\
\hline \multirow[t]{2}{*}{ Model } & & \multicolumn{2}{|c|}{$\begin{array}{l}\text { Unstandardized } \\
\text { Coefficients }\end{array}$} & \multirow{2}{*}{$\begin{array}{c}\begin{array}{c}\text { Standardized } \\
\text { Coefficients }\end{array} \\
\text { Beta }\end{array}$} & \multirow[t]{2}{*}{$\mathbf{t}$} & \multirow[t]{2}{*}{ Sig. } \\
\hline & & B & Std. Error & & & \\
\hline \multirow[t]{3}{*}{1} & (Constant) & 36.108 & 3.520 & & 10.258 & .000 \\
\hline & Kebiasaan Buruk & -.020 & .034 & -.047 & -.602 & .548 \\
\hline & $\begin{array}{l}\text { Kebiasaan New } \\
\text { Normal }\end{array}$ & .159 & .065 & .194 & 2.464 & .015 \\
\hline
\end{tabular}

a. Dependent Variable: kinerja 
Tabel 7. Hasil Uji Hipotesis

\begin{tabular}{cccccc}
\hline Variabel X & Variabel Y & $\begin{array}{c}\text { Unstandarized } \\
\text { Beta }\end{array}$ & Sig & $\mathbf{R}^{2}$ & Keterangan \\
\cline { 1 - 3 } $\begin{array}{c}\text { Kebiasaan } \\
\text { Buruk }\end{array}$ & & $-0,020$ & 0,548 & & $\begin{array}{c}\text { Tidak } \\
\text { Berpengaruh }\end{array}$ \\
\cline { 1 - 1 } $\begin{array}{c}\text { Kebiasaan } \\
\text { New Normal }\end{array}$ & Kinerja & 0,159 & 0,015 & $3,8 \%$ & Berpengaruh \\
\end{tabular}

Sumber: Data Olahan SPSS, 2021

Pada tabel 7 ditunjukan bahwa nilai signifikansi variabel kebiasaan buruk sebesar 0,548 dan pada variabel kebiasaan normal sebesar 0,015. Dari hasil tersebut dapat disimpulkan bahwa tidak terdapat pengaruh kebiasaan diri yang buruk terhadap kinerja dan kebiasaan di era New Normal berpengaruh positif terhadap kinerja. Kebiasaan new normal yang tercipta karena pandemi Covid-19 ini berpengaruh positif terhadap kinerja driver gojek di Salatiga. Perubahan perubahan yang terjadi secara cepat dalam era new normal ini justru memiliki dampak positif terhadap kinerja driver Gojek di Salatiga. Jika dilihat secara simultan dengan nilai signifikansi $0,047<0,05$ maka dapat disimpulkan variabel kebiasaan buruk dan kebiasaan new normal berpengaruh secara simultan terhadap variabel kinerja.

Nilai $R_{\text {square }}$ yang didapat pada uji hipotesis ini adalah sebesar 0,038. Implikasi dari nilai $\mathrm{R}_{\text {square }}$ tersebut adalah pengaruh yang diberikan kebiasaan new normal terhadap kinerja adalah 3,8\% dan sisanya dipengaruhi faktor lain. Persamaan Regresi dari penelitian ini adalah $Y=36,108-0,020 X_{1}+0,159 X_{2}$.

\section{Pembahasan}

Dari hasil penelitian ini, ditemukan beberapa hal yang dapat menjadi implikasi teoritis dan implikasi terapan. Generasi yang lahir antara tahun 1980 hingga tahun 1995 pada saat teknologi telah maju disebut sebagai generasi milenial (Utami, 2021). Pernyataan tersebut dapat diartikan bahwa generasi milenial saat ini berumur sekitar 26 tahun sampai 41 tahun. Pada penelitian ini total responden yang berusia 20-40 tahun merupakan jumlah responden yang dominan yaitu sejumlah 58,75\%.

Kebiasaan new normal yang lahir akibat pandemi Covid19 membuat banyak perubahan dalam kegiatan sehari hari. Perubahan ini diduga akan memberi pengaruh negatif terhadap kinerja driver gojek di Salatiga. Hal ini didasari dengan perubahan yang terjadi seperti menggunakan masker, membersihkan tangan, dan menjaga jarak memungkinkan mengganggu kinerja driver Gojek berhubung mobilitas pekerjaan mereka yang intens. Namun ternyata hasil dari penelitian ini justru menemukan adanya pengaruh yang positif dari kebiasaan new normal terhadap kinerja. Hal ini diduga terjadi karena kebiasaankebiasaan baru tersebut ternyata memiliki manfaat lain selain menjaga diri dari paparan virus Covid19 dan manfaat-manfaat lain tersebut justru meningkatkan kinerja. Seperti penelitian yang dilakukan oleh Ferusgel dan Widya (2019) yang menyatakan bahwa masker sangat berguna dalam meminimalkan paparan debu maupun polutan udara sehingga jumlah debu yang dihirup oleh driver ojek online semakin sedikit. . Dengan berkurangnya kuantitas debu dan polusi yang dihirup maka resiko para driver mengidap penyakit pernafasan dan menyebabkan kinerja menurun kecil terjadi. Kebiasaan meningkatkan imun tubuh dengan cara menjaga pola makan di masa pandemi ini juga sangat bermanfaat untuk energi para driver dalam bekerja. Seperti yang dikatakan Handayani (2020) makan dengan benar akan menyebabkan tidur lebih nyenyak, mempunyai lebih banyak energi dan memiliki konsentrasi yang lebih baik.

Dengan menggunakan pengukuran skala likert hasil rata rata variabel kebiasaan diri yang buruk bernilai tinggi. Salah satu indikator dalam kebiasaan diri yang buruk dalam penelitian ini yaitu kualitas tidur yang buruk. Dalam beberapa penelitian di Indonesia juga sering ditemukan bahwa pekerja di Indonesia mempunyai kualitas tidur yang buruk. Riset yang dilakukan di PT. Kusuma Sandang Mekarjaya Yogyakarta menunjukan rata rata kualitas tidur responden adalah kualitas tidur yang buruk (Trisnawati, 2012).

Indikator lainnya adalah terlalu lama duduk dalam pekerjaan mereka. Hal ini sangat wajar memiliki nilai rata rata yang tinggi dikarenakan pekerjaan mereka yang mengendarai kendaraan bermotor dengan posisi duduk. Disamping itu juga ketika para driver menunggu pesanan dari konsumen umumnya mereka menunggu sambil duduk dan berbincang dengan sesama driver lain.

Variabel kebiasaan new normal juga memiliki nilai rata rata yang tinggi dan ini merupakan suatu hal yang baik. Indikator penilaian seperti menggunakan masker yang baik, menjaga jarak dan meningkatkan imun tubuh dengan makan makanan bergizi jika memiliki nilai yang tinggi, maka dapat dikatakan para driver peka terhadap apa yang terjadi di masa pandemi ini. Kepekaan para driver gojek ini terkait protokol kesehatan terbukti dari penolakan sejumlah 700 ribu pesanan dikarenakan penumpang menolak untuk memakai masker (Kamaliah, 2021). Hal ini menunjukan bahwa pandemi membuat semua lini masyarakat 
mendorong untuk satu sama lain patuh akan protokol kesehatan yang ditetapkan oleh pemerintah. Dengan adanya kesadaran dalam segala lini masyarakat ini diharapkan pandemi segera mereda dan berakhir. Kedisiplinan menaati peraturan yang ada ini kiranya dapat diterapkan lagi jika hal-hal seperti pandemi ini terulang kembali.

Nilai rata-rata variabel kinerja sangat tinggi. Suatu penelitian yang dilakukan menunjukan $81,05 \%$ dari 65 responden yang mana adalah driver gojek Surakarta menunjukan bahwa kinerja driver secara umum tinggi (Mangifera \& Isa, 2017). Kinerja menjadi suatu penilaian kerja bagi driver gojek dan penilaian tersebut berpengaruh terhadap pendapatannya. Pendapatan memiliki dampak positif dan sangat kuat terhadap hasil kerja dan pelayanan para mitra gojek (Darma et al., 2019).

Dalam variabel kinerja ini indikator yang memiliki nilai tertinggi adalah memiliki rasa tanggung jawab dalam mengambil keputusan. Hal ini menunjukan bahwa ada kesadaran dari driver gojek tentang keputusan yang mereka ambil akan mempengaruhi kinerja mereka. Para driver gojek juga memahami bahwa keputusan yang mereka ambil perlu dipertanggung jawabkan. Contohnya saat menolak pesanan dari konsumen, apapun alasannya akan ada konsekuensi yang diterima.

Hasil pengujian menunjukan kebiasaan diri tidak mempengaruhi kinerja. Hal ini dapat diartikan kebiasaan diri yang buruk tidak memiliki pengaruh secara langsung terhadap kinerja para driver gojek Salatiga. Karakteristik para driver dapat menjadi faktor mengapa kebiasaan buruk yang dimiliki tidak mempengaruhi kinerja mereka.

Dalam penelitian ini $80,62 \%$ responden berstatus sudah menikah. Dalam berumah tangga tentu saja ada kebutuhan-kebutuhan dasar yang perlu dipenuhi. Hal ini diperkuat dengan riset yang dibuat oleh (Anggraeni, 2020) menyatakan kebutuhan dasar menjadi satu-satunya sumber motivasi bagi para mitra ojek online untuk mendapatkan kompensasi dengan cara memberikan pelayanan yang ramah pada penumpang. Motivasi yang kuat untuk memenuhi kebutuhan-kebutuhan dasar ini dapat menutupi pengaruh kebiasaan-kebiasaan buruk terhadap kinerja yang menjadi penilaian kerja. Kinerja juga bisa dipengaruhi dari faktor-faktor lain selain kebiasaan diri.

Hasil pengujian menunjukan kebiasaan diri memiliki nilai beta positif yang artinya jika kebiasaan diri buruk tinggi maka kinerja juga tinggi. Kebiasaan buruk driver seperti lupa istirahat dikarenakan kerja hingga larut malam dengan intensitas pekerjaan yang tinggi, menggambarkan kinerja driver yang tinggi pula. Mengkonsumsi kopi secara berlebihan guna menghilangkan kantuk dan meningkatkan kesadaran menunjukan bahwa tujuan utama konsumsi kopi adalah agar lebih fokus bekerja. "Menyelesaikan pekerjaan dengan terlalu lama duduk" menjadi pernyataan yang paling tinggi rata-ratanya dikarenakan pekerjaan driver ojek online adalah mengendarai sepeda motor yang mana dilakukan dengan posisi duduk. Menunggu pesanan dari konsumen juga umumnya dilakukan dalam posisi duduk disaat para driver beristirahat sejenak. Maka dari itu jika pernyataan "Menyelesaikan pekerjaan dengan terlalu lama duduk" memiliki ratarata tinggi artinya kinerja para driver tersebut juga tinggi berhubung pekerjaan mereka dominan dilakukan dalam posisi duduk.

Faktor-faktor lain itu diantaranya adalah kebiasaan new normal. Hasil pengujian menunjukan kebiasaan new normal mempengaruhi kinerja secara positif. Kebiasaan-kebiasaan yang lahir pada era new normal ini secara tak terduga memiliki pengaruh positif terhadap kinerja driver gojek di Salatiga. Kebiasaan baru seperti menggunakan masker, membersihkan tangan, menjaga jarak, menjaga serta meningkatkan imun tubuh ternyata berpengaruh positif terhadap kinerja yang menjadi penilaian kerja para driver gojek di Salatiga.

Penelitian yang dilakukan di kota Medan oleh Ferusgel dan Widya (2019)menyatakan bahwa masker sangat berguna dalam meminimalkan paparan debu maupun polutan udara sehingga jumlah debu yang dihirup oleh driver ojek online semakin sedikit. Penggunaan masker pada masa pandemi ini tidak hanya melindungi driver ojek online dari paparan virus Covid-19 namun dari paparan penyakit yang biasanya disebabkan oleh debu di jalanan juga. Akibat penggunaan masker secara lebih rutin dalam masa pandemi ini, penyakit-penyakit saluran pernafasan yang dapat mengganggu kinerja driver menjadi terhindari.

Kesadaran para driver ojek online akan imunitas tubuh yang perlu diperhatikan di masa pandemi ini juga menjadi hal yang berpengaruh dalam kinerja mereka. Makan dengan benar akan menyebabkan tidur lebih nyenyak, mempunyai lebih banyak energi dan memiliki konsentrasi yang lebih baik (Handayani, 2020). Sesuai dengan pernyataan tersebut menjaga pola makan guna meningkatkan imun tubuh memiliki banyak manfaat untuk driver ojek online, seperti mendapat kualitas tidur yang lebih baik dan energi serta konsentrasi yang cukup saat bekerja. 


\section{Simpulan dan saran \\ a. Simpulan}

Berdasarkan hasil pengujian dan pembahasan, maka dapat disimpulkan kebiasaan diri yang buruk tidak memiliki pengaruh terhadap kinerja driver Gojek di Salatiga. Hal ini dibuktikan dengan angka signifikansi yang dimiliki sebesar 0,548 lebih besar dari $0,05(0,548>0,05)$. Hasil pengujian dan pembahasan juga menyimpulkan kebiasaan di era new normal berpengaruh positif terhadap kinerja driver Gojek di Salatiga. Hal tersebut dibuktikan dengan angka signifikansi yang dimiliki sebesar 0,015 lebih kecil dari $0,05(0,015<0,05)$. Variabel kebiasaan new normal memiliki pengaruh sebesar $3,8 \%$ terhadap kinerja dan sisanya dipengaruhi oleh faktor-faktor lain. Variabel kebiasaan buruk dan kebiasaan new normal secara simultan berpengaruh terhadap variabel kinerja, dilihat dari nilai signifikansi sebesar 0,047 yang mana lebih kecil dari 0,05 $(0,047<0,05)$. Kebiasaan buruk memiliki nilai beta unstandardized yang positif sebesar 0,034 yang artinya jika kebiasaan buruk tinggi maka kinerja juga ikut tinggi. Kebiasaan di era new normal juga memiliki nilai beta unstandardized yang positif sebesar 0,065 yang artinya jika kebiasaan di era new normal tinggi maka kinerja juga tinggi.

\section{b. Implikasi}

Penelitian ini mendapatkan hasil yang bertolak belakang dengan riset yang dilakukan oleh Beaton (2017) yang mengatakan generasi milenial merupakan generasi yang tidak produktif dibandingkan dengan generasi generasi yang lain dikarenakan beberapa kebiasaan buruk seperti sistem tidur yang buruk, pola makan yang tidak baik, meminum kopi, durasi duduk yang tidak baik, penggunaan telepon yang berlebihan, waktu kerja yang tidak teratur, menonton TV secara berlebihan dan nongkrong dengan orang yang mudah cemas. Pada penelitian ini kebiasaan kebiasaan yang disebutkan tidak berpengaruh terhadap kinerja driver Gojek di Salatiga.

Dilihat dari hasil penelitian ini, maka implikasi terapan yang diperoleh adalah kebiasaan diri yang buruk tidak berpengaruh secara langsung terhadap kinerja namun ada baiknya jika dibenahi. Kebiasaan buruk seperti lupa untuk istirahat ada baiknya untuk diatasi dengan bekerja dengan waktu yang teratur dan terencana. Driver gojek disarankan untuk menetapkan jumlah waktu bekerja per hari dan sisa waktu yang dimiliki per harinya digunakan untuk berisitrahat di rumah. Ada baiknya lagi jika pihak perusahaan Gojek yang mempekerjakan para driver ini membuat kebijakan yang tepat tentang waktu kerja sehingga mereka memiliki waktu yang seimbang antara bekerja dan beristirahat.

Menyelesaikan pekerjaan dengan terlalu lama duduk merupakan kebiasaan yang bu ruk namun bagi driver gojek hal itu sulit dihindari karena pekerjaan mereka adalah mengendarai sepeda motor. Saat menunggu pesanan dari konsumen gojek, driver sebaiknya menunggu dengan posisi berdiri guna mengurangi lamanya durasi duduk per hari. Dalam penelitian ini ditemukan kebiasaan buruk lainnya yang cukup sering dilakukan driver gojek adalah terlalu sering menggunakan ponsel untuk menelfon. Dengan menggunakan fitur pesan singkat dari berbagai aplikasi pada ponsel para driver, waktu dan energi yang digunakan akan lebih efisien.

Implikasi terapan lain yang ada dalam penelitian ini adalah kebiasaan new normal merupakan kebiasaan yang baik untuk dilakukan bukan hanya untuk melindungi diri dalam pandemi Covid19. Penggunaan masker secara rutin dalam masa pandemi dengan tujuan melindungi diri dari paparan virus Covid19 justru memiliki fungsi lain bagi driver gojek yaitu mengurangi paparan debu dan polutan udara yang berpotensi untuk menyebabkan penyakit-penyakit saluran pernafasan yang dapat mengganggu kinerja driver gojek. Oleh karena itu penggunaan masker secara rutin disarankan selalu dan tetap diterapkan dikala pandemi berakhir. Kebiasaan lain yang ada dalam masa new normal ini seperti menjaga imun tubuh dan menjaga kebersihan juga ada baiknya selalu diterapkan dalam kehidupan guna meningkatkan kinerja dan kualitas hidup driver gojek di Salatiga. Perusahaan Gojek sebagai yang mempekerjakan para driver ini juga disarankan lebih memperhatikan kesehatan dan kualitas hidup para driver dengan membuat kebijakan-kebijakan serta bantuan lebih terhadap para driver ini di masa pandemi.

\section{Keterbatasan Penelitian dan Penelitian yang Akan Datang}

Keterbatasan penelitian ini adalah variabel bebas pada penelitian ini merupakan topik yang jarang diteliti terutama untuk variabel kebiasaan new normal dikarenakan kebiasaan tersebut adalah fenomena yang baru terjadi. Keterbatasan lainnya adalah objek penelitian yang berasal hanya dari satu daerah saja yaitu Salatiga yang merupakan kota kecil. Keterbatasan lain dalam penelitian ini yaitu indikator kinerja dan kebiasaan-kebiasaan ini hanya diukur berdasarkan persepsi sehingga dapat menimbulkan bias high tendency atau menilai terlalu tinggi.

Disarankan untuk penelitian selanjutnya memperluas objek penelitian sehingga mendapatkan data yang lebih baik. Selain memperluas objek penelitan, peneliti selanjutnya disarankan mempersiapkan diri dengan baik saat akan mengambil dan mengumpulkan data agar proses tersebut dapat berlangsung secara 
baik pula. Seiring berjalan waktu juga akan ada penelitan-penelitian mengenai kebiasaan new normal yang lebih banyak sehingga akan menjadi sumber referensi yang lebih kuat. Penelitian berikutnya disarankan untuk menelaah lebih banyak sumber maupun referensi yang berhubungan dengan kebiasaan serta kinerja sehingga hasil penelitian dapat menjadi lebih baik dan lebih dalam lagi.

\section{Daftar Rujukan}

Anggraeni, F. N. (2020). Survey Motivasi Kerja Driver Ojek Online Grab. Scientific Journal of Reflection: Economic, Accounting, Management and Business, 3(3), 251-260. https://doi.org/10.5281/zenodo.3930682

Anggraini, A. P. (2019). Pola Makan yang Buruk Bisa Sebabkan Kematian. Lifestyle.Kompas.Com. https://lifestyle.kompas.com/read/2019/05/28/142038520/pola-makan-yang-buruk-bisasebabkan-kematian?page=all

Anwar, F. (2016). 5 Dampak Buruk Menonton TV Terlalu Lama Terhadap Kesehatan. Health.Detik.Com. https://health.detik.com/berita-detikhealth/d-3261524/5-dampak-buruk-menonton-tv-terlalulama-terhadap-kesehatan

Arianto, D. A. N. (2013). Pengaruh Kedisiplinan, Lingkungan Kerja Dan Budaya Kerja Terhadap Kinerja Tenaga Pengajar. Jurnal Economia, 9(2), 191-200. https://doi.org/10.21831/economia.v9i2.1809

Bahri, S., Syarifuddin, \& Gunawan. (2012). Analisis Penentuan Waktu Istirahat Pendek Berdasarkan Beban Kerja Fisik dan Asupan Energi. Industrial Engineering Journal, 1(1), 30-35.

Beaton, C. (2017). 8 Habits That Make Millennials Stressed And Unproductive. Psychologytoday.Com.

Bissell, D. (2013). Habit displaced: The disruption of skilful performance. Geographical Research, 51(2), 120-129. https://doi.org/10.1111/j.1745-5871.2012.00765.x

Clinten, B. (2020). PSBB Jakarta, Penumpang GoCar dan GrabCar Maksimal 2 Orang. Tekno.Kompas.Com. https://tekno.kompas.com/read/2020/04/10/14441247/psbb-jakarta-penumpang-gocar-dangrabcar-maksimal-2-orang?page=all

Covey, S. R. (2004). The seven habits of highly effective drug discoverers? Nature Reviews Drug Discovery, 3(4), 285. https://doi.org/10.1038/nrd1375

Darma, G. S., Wicaksono, K., Sanica, I. G., \& Abiyasa, A. P. (2019). Faktor Kompensasi Dan Strategi Gojek Dalam Meningkatkan Kepuasan Kerja Para Driver. JMBI UNSRAT (Jurnal Ilmiah Manajemen Bisnis Dan Inovasi Universitas Sam Ratulangi)., 6(3), 232-244. https://doi.org/10.35794/jmbi.v6i3.27105

Djuharni, D., \& Pangesti, W. D. (2020). Makna Bonus Bagi Pengemudi Transportasi Online. Akuntansi Bisnis Dan Manajemen (ABM), 27(1), 66-76.

Ebele, U. F., \& Olofu, P. A. (2017). Study habit and its impact on secondary school students academic performance in biology in the Federal Capital Territory, Abuja. Educational Research and Reviews, 12(10), 583-588. https://doi.org/10.5897/err2016.3117

Effendi, S. (2013). The Effect Of Entrepreneurship Orientation On The Small Business Performance With Government Role As The Moderator Variable And Managerial Competence As The Mediating Variable On The Small Business of Apparel Industry In Cipulir Market, South Jakarta. IOSR Journal of BusinesS and Management. https://doi.org/10.9790/487x-0814955

Ferusgel, A., \& Widya, A. (2019). Keluhan Kesehatan Pernapasan Pada Driver Ojek Online di Medan. VISIKES: Jurnal Kesehatan Masyarakat, 18(2), 1-8.

Giri, P. C., \& Dewi, M. H. U. (2017). Analisis Faktor-Faktor yang Mempengaruhi Pendapatan Driver Go-Jek di Kota Depansar Bali. E-Jurnal EP Unud, 6(6), 948-975.

Gojek. (2020). PSBB Kembali Berlaku? Gojek Tetap Jadi Andalan Menjalani Hari yang Produktif. Gojek.Com.

Hair, J. F., Black, W. C., Babin, B. J., \& Anderson, R. E. (2014). Seventh Edition Multivariate Data Analysis (Pearson Ne). Pearson Custom Library. www.pearsoned.co.uk

Handayani, dr. V. V. (2020). Alasan Pentingnya Olahraga dan Pola Makan Sehat Untuk Diet. Halodoc.Com. https://www.halodoc.com/artikel/alasan-pentingnya-olahraga-dan-pola-makan-sehat-untuk-diet

Hapsari, V. C., Sovitrina, R., \& Santosa, A. D. (2021). Stress Pada Pengemudi Ojek Online Di Pandemic Covid19 Masa New Normal Di Jakarta. IKRA-ITH Humaniora, 5(1), 29-38.

Ismawati, R., Wicaksono, A. B., \& Rahayu, R. (2019). Kebiasaan Buruk Para Pengunyah Sirih. Prosiding Seminar Nasional MIPA Kolaborasi, 2(1), 218-222.

Kamaliah, A. (2021). 700 Ribu Order Ditolak Driver Gojek karena Penumpang Tak Bermasker. Inet.Detik.Com. https://inet.detik.com/business/d-5333910/700-ribu-order-ditolak-driver-gojek-karenapenumpang-tak-bermasker

Kartika, L. N., \& Sugiarto, A. (2016). Pengaruh Tingkat Kompetensi Terhadap Kinerja Pegawai Administrasi Perkantoran. Jurnal Ekonomi Dan Bisnis, 17(1), 73. https://doi.org/10.24914/jeb.v17i1.240

Lailiyah, U. W., \& Wahyuningsih, T. harsini. (2019). Analisis Faktor-Faktor Yang Mempengaruhi Kinerja Driver Grab-Bike Kabupaten Banjarnegara. Jurnal Manajemen Dan Bisnis Media Ekonomi, XIX(1), 190- 
201.

LaRose, R., Lin, C. A., \& Eastin, M. S. (2003). Unregulated Internet usage: Addiction, habit, or deficient selfregulation? Media Psychology, 5(3), 225-253. https://doi.org/10.1207/S1532785XMEP0503_01

Madona, E., Irmansyah, M., Nasution, A., \& Syafitri, D. (2018). Sistem Informasi Untuk Posisi Dan Lama Duduk Berbasis Android. Seminar Nasional Teknologi Informasi, Komunikasi Dan Industri (SNTIKI-10) Fakultas Sains Dan Teknologi, UIN Sultan Syarif Kasim Riau, November, 143-150.

Mangifera, L., \& Isa, M. (2017). Komitmen dan Kinerja Driver Ojek Online di Kota Surakarta. Prosiding, ISBN 978-6, 507-515.

Mangkunegara, A. P. (2012). Evaluasi Kinerja SDM, cetakan keenam. In Bandung: Refika Aditama.

Mas'udi, W., \& Winanti, P. S. (2020). Response masyarakat sipil atas norma 'adaptasi kebiasaan baru (Issue August).

Mathis, L. R., \& Jackson, H. J. (2019). Human Resource Management: Personnel Human Resource Management. In Harvard Business Review (13th ed.).

Muhyiddin, \& Kementerian Perencanaan Pembangunan Nasional/Bappenas Republik Indonesia. (2020). Covid-19, New Normal, dan Perencanaan Pembangunan di Indonesia. Jurnal Perencanaan Pembangunan: The Indonesian Journal of Development Planning, 4(2), 240-252. https://doi.org/10.36574/jpp.v4i2.118

Murty, W. A., \& Hudiwinarsih, G. (2012). Pengaruh Kompensasi, Motivasi Dan Komitmen Organisasional Terhadap Kinerja Karyawan Bagian Akuntansi (Studi Kasus Pada Perusahaan Manufaktur Di Surabaya). The Indonesian Accounting Review, 2(02), 215. https://doi.org/10.14414/tiar.v2i02.97

Neal, D. T., Wood, W., \& Quinn, J. M. (2006). Habits-A Repeat Performance. Current Directions in Psychological Science, 15(4), 198-203.

Niswah, M. (2016). Hubungan Antara Pola Makan Sehari-Hari Dan Gaya Hidup Sehat Dengan konsentrasi dan prestasi Belajar. Naskah Publikasi Hasil Skripsi, 1(2), 30-50.

Nofian, A. (2020). Statqo: Dampak Corona, Transportasi Online Turun Drastis. Goodmoney.Id.

Nonis, S. A., \& Hudson, G. I. (2010). Performance of College Students: Impact of Study Time and Study Habits. Journal of Education for Business, 85(4), 229-238. https://doi.org/10.1080/08832320903449550

Nursalam, \& Jamaluddin, A. (2016). Konstruksi Sosial Media Komunikasi Instagram Terhadap Pola Pikir. Jurnal Equilibrium Jurnal Equilibrium Pendidikan Sosiologi, IV(2), 233-242.

Pertiwi, W. K. (2020). Gojek PHK 430 Karyawan, Bagaimana Nasib Driver Ojol? Tekno.Kompas.Com.

Reuter, P. R., Forster, B. L., \& Brister, S. R. (2020). The influence of eating habits on the academic performance of university students. Journal of American College Health, o(0), 1-7. https://doi.org/10.1080/07448481.2020.1715986

Safitrie, A., \& Ardani, M. H. (2013). Studi Komparatif Kualitas Tidur Perawat Shift dan Non Shift di Unit Rawat Inap dan Unit Rawat Jalan. Prosiding Konferensi Nasional PPNI Jawa Tengah, 17-23.

Siagian, T. H. (2020). Corona Dengan Discourse Network Analysis. Jurnal Kebijakan Kesehatan Indonesia, 09(02), 98-106.

Silva, M. R. G., \& Paiva, T. (2016). Poor precompetitive sleep habits, nutrients' deficiencies, inappropriate body composition and athletic performance in elite gymnasts. European Journal of Sport Science, 16(6), 726-735. https://doi.org/10.1080/17461391.2015.1103316

Sofyan, D. K. (2013). Pengaruh Lingkungan Kerja Terhadap Kinerja Kerja Pegawai BAPPEDA. Malikussaleh Industrial Engineering, 2(1), 18-23.

Solikatun, S., Kartono, D. T., \& Demartoto, A. (2015). Perilaku Konsumsi Kopi Sebagai Budaya Masyarakat Konsumsi (Studi Fenomenologi Pada Peminum Kopi Di Kedai Kopi Kota Semarang). Jurnal Analisa Sosiologi, 4(1), 60-74.

Tahir, M., Haiy, A. U., Tahir, M., Kuraishi, R. T., \& Saqib, S. (2014). Sleeping Habits among Medical Students of King Edward Medical University, Associated Stress and Effects on Academic Performance. 1-6.

Takeda, T., Yoshimi, K., Imoto, Y., \& Shiina, M. (2020). Associations between sleep habits and interference of premenstrual symptoms in athletic performance in Japanese adolescent athletes: a cohort study over a 2-year period. Gynecological Endocrinology, 36(10), 885-889. https://doi.org/10.1080/09513590.2020.1734787

Tashandra, N. (2020). 6 Tanda Tubuh Terlalu Banyak Minum Kopi. Lifestyle.Kompas.Com. https://lifestyle.kompas.com/read/2020/01/23/075855420/6-tanda-tubuh-terlalu-banyakminum-kopi?page=all

Titus, A. B., Dada, A. B., \& Adu, E. O. (2016). Effects of Social Habits and Girl-child Marriage on Students Academic Performance in Social Studies. Journal of Sociology and Social Anthropology, 7(4), 250-255. https://doi.org/10.1080/09766634.2016.11885723

Trisnawati, E. (2012). Kualitas tidur, status gizi dan kelelahan kerja pada pekerja wanita dengan peran ganda. Prosiding Seminar Nasional Kesehatan, 1-16. 
Utami, S. N. (2021). Jangan Tertukar, Ini Pengertian Generasi X, Z, Milenial, dan Baby Boomers. Kompas.Com. https://www.kompas.com/skola/read/2021/04/17/130000069/jangan-tertukar-ini-pengertiangenerasi-x-z-milenial-dan-baby-boomers\#content-3

Webb, T. L., Sheeran, P., \& Luszczynska, A. (2009). Planning to break unwanted habits: Habit strength moderates implementation intention effects on behaviour change. British Journal of Social Psychology, 48(3), 507-523. https://doi.org/10.1348/014466608X370591

Willy, dr. T. (2019). Gangguan Tidur. Alodokter.Com. https://www.alodokter.com/gangguan-tidur

World Health Organization. (2020a). New Normal. Who.Int. https://www.who.int/indonesia/news/novelcoronavirus/new-infographics/new-normal

World Health Organization. (2020b). Transmission of SARS-CoV-2: implications for infection prevention precautions. Who.Int.

Yayasan Lembaga Konsumen Indonesia. (2017). Warta Konsumen: Transportasi Online; Kawan atau Lawan? Ylki.or.Id. 